\title{
Inhibitory Role of Dietary Protein Restriction on the Development and Expression of Immune-mediated Antitubular Basement Membrane-induced Tubulointerstitial Nephritis in Rats
}

\author{
David Agus, Richard Mann, Debbie Cohn, Lauren Michaud, Carolyn Kelly, Michael Clayman, and Eric G. Neilson \\ Renal-Electrolyte Section, Department of Medicine, University of Pennsylvania School of Medicine, Philadelphia, Pennsylvania 19104
}

\begin{abstract}
The protective effect of dietary protein restriction on the development and expression of immune-mediated interstitial nephritis was evaluated in Brown Norway rats with anti-tubular basement membrane disease. In the first series of experiments, pair-fed rats received low protein (LP) (3\% casein) or normal protein (NP) (27\% casein), normocaloric diets. After 6 wk, each group was immunized with renal tubular antigen in adjuvant to produce anti-tubular basement membrane antibody ( $\alpha$ TBM-Ab) and tubulointerstitial nephritis. The kidneys harvested from NP rats after four more weeks on the diet had histologically more severe interstitial disease than the LP rats (histologic severity; NP $=3.1 \pm 0.2$ vs. $L P=1.1 \pm 0.3 ; P<0.001)$, and serum creatinine values were concordantly different $(\mathrm{NP}=1.34 \pm 0.02$ vs. $\mathrm{LP}$ $=0.82 \pm 0.03)$. Titers of $\alpha \mathrm{TBM}-\mathrm{Ab}$ were similar in both groups, while the $T$ cell-mediated immune response, as measured by delayed-type hypersensitivity (DTH), was nonspecifically impaired in LP rats when compared with the NP group. Admixture cotransfers of LP plus NP cells failed to demonstrate active suppression as an explanation for the depressed DTH in LP rats. The therapeutic role of dietary protein restriction was also examined in rats with established $\alpha$ TBM disease. In these experiments, rats were first immunized and fed NP diets for 4 wk (histologic severity $=3.0 \pm 0.2$; creatinine $=1.78 \pm 0.02$ ), and then were divided into two groups and followed for six more weeks on either LP or NP diets. LP rats, under these conditions, developed less disease than those fed NP diet (histologic severity; $\mathrm{NP}=3.2 \pm 0.3$ vs. $\mathrm{LP}=1.4 \pm 0.2 ; P<0.001$ ), and serum creatinine values were concordantly different $(N P=1.92 \pm 0.05$ vs. $L P=0.97 \pm 0.02)$. Again, the titers of $\alpha \mathrm{TBM}-\mathrm{Ab}$ in both $\mathrm{LP}$ and NP groups were similar. These data collectively suggest that LP diet has a protective effect both on the development and extent of tubulointerstitial nephritis that is perhaps, in part, related to the selective abrogation of effector $T$ cell immunity.
\end{abstract}

\section{Introduction}

An association between levels of protein ingestion and the development of renal disease was first reported by Newburgh in 1919 (1). Subsequent studies have confirmed that increased protein intake can promote or accelerate progressive renal insuffi-

\footnotetext{
Address reprint requests to Dr. Neilson.

Received for publication 28 December 1984 and in revised form 15
} March 1985.

\section{J. Clin. Invest.}

(c) The American Society for Clinical Investigation, Inc.

0021-9738/85/09/0930/07 \$1.00

Volume 76, September 1985, 930-936 ciency (2). Several theories presently exist to explain how dietary protein may influence the course of renal injury. One nonimmunologic view suggests that renal impairment leads to a retention of nephrotoxic protein-derived metabolites, which accelerates further damage (3). A corollary of this notion is that impaired renal function also causes phosphate retention which leads to secondary hyperparathyroidism and nephrocalcinosis (4). It has also been recently proposed that increased dietary protein induces a persistent rise in glomerular capillary plasma flow with hyperfiltration in the glomerular tuft (5). The high flow and increased pressure eventually disrupt capillary basement membranes, which leads to alterations in the mesangium-producing glomerulosclerosis with progressive renal failure. This process is accelerated in the presence of preexisting renal disease when hyperfiltration is produced from nephron loss consequent to the original insult.

While one, or all, of these theories may well help to explain the effects of dietary ingestion on the pathogenesis of progressive glomerular injury, these ideas, for the most part, have been experimentally tested in nonimmunologic models of renal failure producing nonspecific glomerulosclerosis. As such, they do not take into account the fact that changes in dietary protein, calories, and lipids may also affect the immune system $(2,6)$, that most forms of glomerular and interstitial nephritis have an immunologic basis (7), and that all progressive glomerular lesions are accompanied by the development of tubulointerstitial nephritis (8-10).

The effects of protein restriction, noted above, have not been formally evaluated in models of immune-mediated interstitial nephritis. Whether in its primary form or as a component of advancing glomerulonephritis, interstitial nephritis is a principal and final common pathway of progressive renal injury. It has been further suggested that a decline in renal function does not occur in glomerulonephritis until the interstitial histopathology is pronounced (8-10). Primary interstitial nephritis has been implicated as a cause of $11-13 \%$ of acute renal failure, and in $25 \%$ of all cases of chronic renal failure $(11,12)$. Because of its obvious importance, the mechanism and pathogenesis of tubulointerstitial nephritis has been intensively studied in experimental animals (13-17). Our laboratory has used a rat model of immune-mediated interstitial injury (anti-tubular basement membrane disease) which results in the development of antitubular basement membrane antibodies ( $\alpha \mathrm{TBM}-\mathrm{Ab}),{ }^{1}$ mononuclear cell infiltrates, tubular atrophy, and fibrosis. Nephritis

1. Abbreviations used in this paper: BN, Brown Norway rats; CFA, complete Freund's adjuvant; DTH, delayed-type hypersensitivity; LP, low protein (3\%), normocaloric diet; NP, normal protein (27\%), normocaloric diet; PPD, purified protein derivative; RTA, renal tubular antigen; SRTA, soluble RTA; $\alpha$ TBM-Ab, anti-tubular basement membrane antibody; $\mathrm{C}^{\prime}$, complement. 
is induced by immunizing Brown Norway rats $(\mathrm{BN})$ with renal tubular basement membranes (RTA) in complete Freund's adjuvant (CFA) (16, 17). $\alpha$ TBM-Ab appear within $10 \mathrm{~d}$ of immunization, and an intense infiltrate with associated fibrosis is seen by 3-4 wk. The present study was designed to determine the effects of protein restriction on the development and extent of interstitial injury in this model of immunologic renal disease.

\section{Methods}

Animals and animal care. Brown Norway rats, weighing 100-120 g, were purchased from the Charles River Breeding Laboratories, Wilmington, MA, and maintained by the Department of Laboratory and Animal Medicine, University of Pennsylvania School of Medicine. Animals were kept in individual metabolic cages, humidity and temperature were controlled, pair feeding was done at the same time daily, and $12 \mathrm{~h}$ of light and $12 \mathrm{~h}$ of darkness were provided.

Preparation of antigens. Rabbit RTA were isolated by a differential sieving technique (13). Highly enriched basement membrane fragments were sonicated, lyophilized, and stored in $-70^{\circ} \mathrm{C}$. Soluble renal tubular antigens (SRTA) were made from these lyophilized membranes using collagenase digestion $(14,16,18)$. Purified protein derivative (PPD) was obtained from Connaught Laboratories, Ontario, Canada.

Induction of disease. Groups of rats were immunized with $2 \mathrm{mg}$ of RTA in CFA by subcutaneous injection $(16,17,19)$. Control animals received CFA alone.

Diets and dietary regimen. Two diets were used, differing only in protein content, as follows: (1) normal protein (NP; $27 \%$ casein, $3.9 \mathrm{kcal} /$ g) or (2) low protein (LP; $3 \%$ casein, $3.9 \mathrm{kcal} / \mathrm{g}$ ). Both were standard AIN-76A diets containing an equivalent amount $(10-\mathrm{g} / \mathrm{kg}$ diet) of AIN$76 \mathrm{~A}$ vitamin mix and an equivalent amount $(3.5-\mathrm{g} / \mathrm{kg}$ diet $)$ of AIN-76A salt mix (20), ensuring normal daily intake of calcium, phosphate, and zinc in all groups. Diets (Dyets, Inc., Bethlehem, PA) were in gel form ( $1.3 \%$ agar) to increase palatability and for efficient measurement of food consumption.

Two sets of experiments were performed. In the first, animals were divided into two groups and received either LP or NP pair-fed diets from day 0 until killing on day 70 . This group was immunized to produce disease on day 42 . In the second experiment, all animals were immunized on day 0 and were fed NP diet until day 28 , when they were divided into two groups and fed either NP or LP diets until killing on day 70.

Assessment of renal disease. Kidney tissue was prepared for immunoflourescent and light microscopy by standard methods for this laboratory $(14,19)$. Direct immunoflourescence of tubular staining by $\alpha$ TBM$\mathrm{Ab}$ was qualitatively graded from 0 to $4+$ and expressed as mean \pm SEM for each group (16). Kidneys fixed in $10 \%$ formalin were sectioned and stained with hematoxylin and eosin, coded, and graded according to the extent of involved cortical area using established criteria $(14,19)$ : $0=$ normal; $0.5=$ small focal areas of cellular infiltration; $1=$ cellular infiltration and tubular damage involving $<10 \%$ of the cortex; $2=$ involvement up to $25 \%$ of the cortex; $3=$ involvement up to $50-75 \%$ of the cortex, and $4=$ extensive damage involving $>75 \%$ of the cortex. Scores for each experimental group were averaged and expressed as a mean \pm SEM. The presence of $\alpha \mathrm{TBM}-\mathrm{Ab}$ and titers of these antibodies were also determined by a solid-phase radioimmunoassay (16). $50 \mu \mathrm{l}$ of SRTA $(12 \mu \mathrm{g} / \mathrm{ml})$ was added to the wells of PVC microtiter plates and kept at $4^{\circ} \mathrm{C}$ over night. Wells were blocked with $4 \%$ bovine serum albumin (BSA), overlain with serial dilutions of test antisera, and subsequently incubated with affinity purified ${ }^{125} \mathrm{I}$-rabbit anti-rat IgG. This assay is specific for $\alpha \mathrm{TBM}-\mathrm{Ab}(16)$. Serum creatinine was measured by the method of Jaffe (21).

Adoptive transfer and measurement of delayed-type hypersensitivity (DTH) to tubular antigen. Draining lymph node and spleen cells were harvested and pooled from immune (RTA/CFA or CFA) donor animals who had received either NP or LP diets. Single cell suspensions were washed, counted, and $20 \times 10^{6}$ donor cells/rat were intravenously injected into naive recipients using phosphate-buffered saline (PBS) as the vehicle (22). In some groups, these cells were $T$ cell depleted with a monoclonal IgM anti-RT7.1 antibody (from BC84.5 hybridoma, provided by Dr. John Ely and Dr. Frank Fitch, University of Chicago, Chicago, IL) and a mixture of rabbit and guinea pig complement $\left(C^{\prime}\right)(22)$. Shortly after receiving the syngeneic donor cells, the recipients were challenged in the footpad with $50 \mu \mathrm{g}$ of soluble antigen in $50 \mu \mathrm{l}$ of PBS. Swelling, as an index of DTH, was measured $24 \mathrm{~h}$ later using a spring-loaded engineer's micrometer (Schlesinger's for Tools, Ltd., Brooklyn, NY). The magnitude of swelling was expressed as the increment between a challenged footpad and prechallenged footpad in inches $\times 10^{-3}$ and reported as the mean \pm SEM (22). All measurements were cage blind. The significance of the difference in means of various groups was tested using $t$ test.

\section{Results}

In the first series of experiments, we analyzed the effects of dietary protein restriction on the development of anti-tubular basement membrane disease producing interstitial nephritis. Groups of rats were fed either LP or NP diets for $42 \mathrm{~d}$ and were then immunized with either RTA/CFA or CFA alone. In Table I, at $70 \mathrm{~d}$, the NP group immunized with RTA/CFA developed significant interstitial nephritis (comparable with other studies [22]), while the group receiving LP diet had less disease. Representative interstitial lesions from these two groups can be observed in Fig. 1. Serum creatinine values concordantly reflected the extent of interstitial involvement. The NP group also gained weight during

Table I. Effects of Protein Restriction on the Development of Interstitial Nephritis

\begin{tabular}{|c|c|c|c|c|c|c|c|}
\hline \multicolumn{2}{|l|}{ Day 0} & \multicolumn{2}{|l|}{ Day 42} & \multicolumn{4}{|l|}{ Day 70} \\
\hline $\operatorname{Diet}^{*}$ & Weightł & Immunization§ & Weight & Weight & $\begin{array}{l}\text { Serum } \\
\text { creatinine" }\end{array}$ & $\begin{array}{l}\text { Histological } \\
\text { severity }\end{array}$ & Bound $\alpha \mathrm{TBM}-\mathrm{Ab}$ \\
\hline NP & 113 & RTA/CFA & 160 & 156 & $1.34 \pm 0.02$ & $3.1 \pm 0.2(5)^{* *}$ & $3.0 \pm 0.3$ \\
\hline NP & 114 & CFA & 159 & 160 & $0.70 \pm 0.04$ & $0.0 \pm 0.0(5)$ & $0.0 \pm 0.0$ \\
\hline LP & 117 & RTA/CFA & 121 & 118 & $0.82 \pm 0.03$ & $1.1 \pm 0.3(5)$ & $3.2 \pm 0.4$ \\
\hline LP & 117 & CFA & 120 & 119 & $0.79 \pm 0.03$ & $0.0 \pm 0.0(5)$ & $0.0 \pm 0.0$ \\
\hline
\end{tabular}

* Animals were fed either the LP or NP diet from day 0 until day 70. $¥$ Weight reported as the mean in grams. § Animals were immunized with either RTA in CFA or CFA alone on day 42. "Serum creatinines (mean mg\% \pm SEM). I Graded histological sections reported as the mean extent of cortical interstitial involvement $\pm \operatorname{SEM}(n) .{ }^{* *} P<0.001$, compared with LP-RTA/CFA group. 


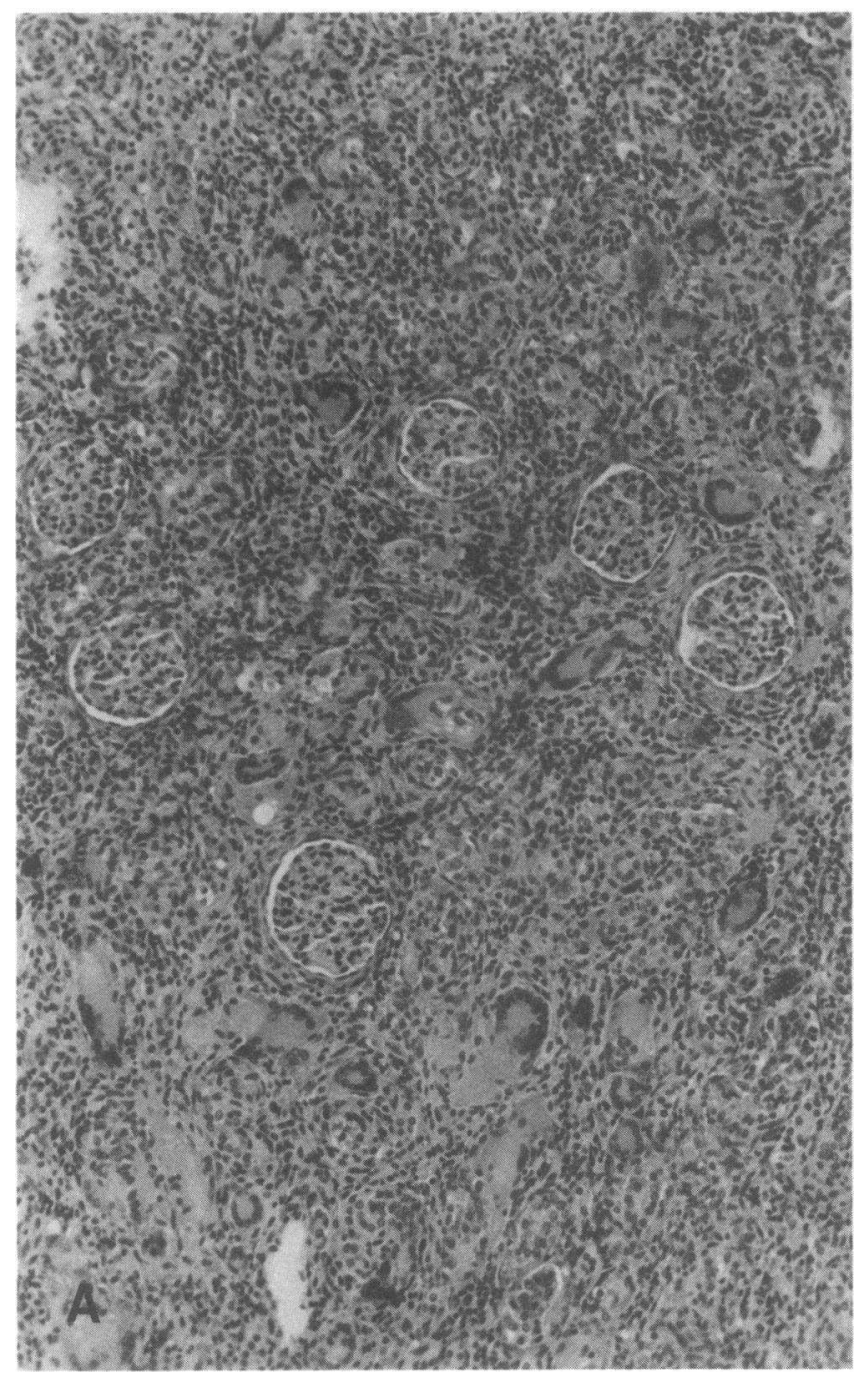

Figure 1. Representative renal lesions from rats immunized $42 \mathrm{~d}$ after the start of LP diet (Table I). Histology was prepared from kidneys killed 4 wk after immunization with RTA in CFA: $(A)$ NP diets. In all areas, the tubular architecture is disrupted by mononuclear cells resulting in destructive damage to the tubulointerstitium. The glo-

the preimmunization diet period, but did not gain further weight after immunization (Table I), while the LP group did not gain or lose weight during the course of the experiment.

In Fig. $2 A$, both LP and NP rats immunized with RTA/ CFA expressed equal amounts of $\alpha \mathrm{TBM}-\mathrm{Ab}$ in the serum by radioimmunoassay, which was reflected in similar amounts of $\alpha$ TBM-Ab bound to the tubules by direct immunoflourescence (Table I). In order to determine the effect of LP diet on the effector $\mathrm{T}$ cell response, we adoptively transferred immune cells into naive recipients and measured their DTH response to SRTA and PPD. We have previously shown that the DTH response to SRTA in this model is tubular antigen-specific, T cell-dependent, and an accurate reflection of nephritogenic potential in diseasesusceptible rats (22). In Table II, we observed that immune cells (RTA/CFA) from the NP group produced DTH to SRTA and PPD, while the CFA group only responded to PPD. Rats on LP diet who were then immunized with RTA/CFA produced significantly less DTH to SRTA and PPD. The DTH response of donor immune cells from the NP group was eliminated by treat-

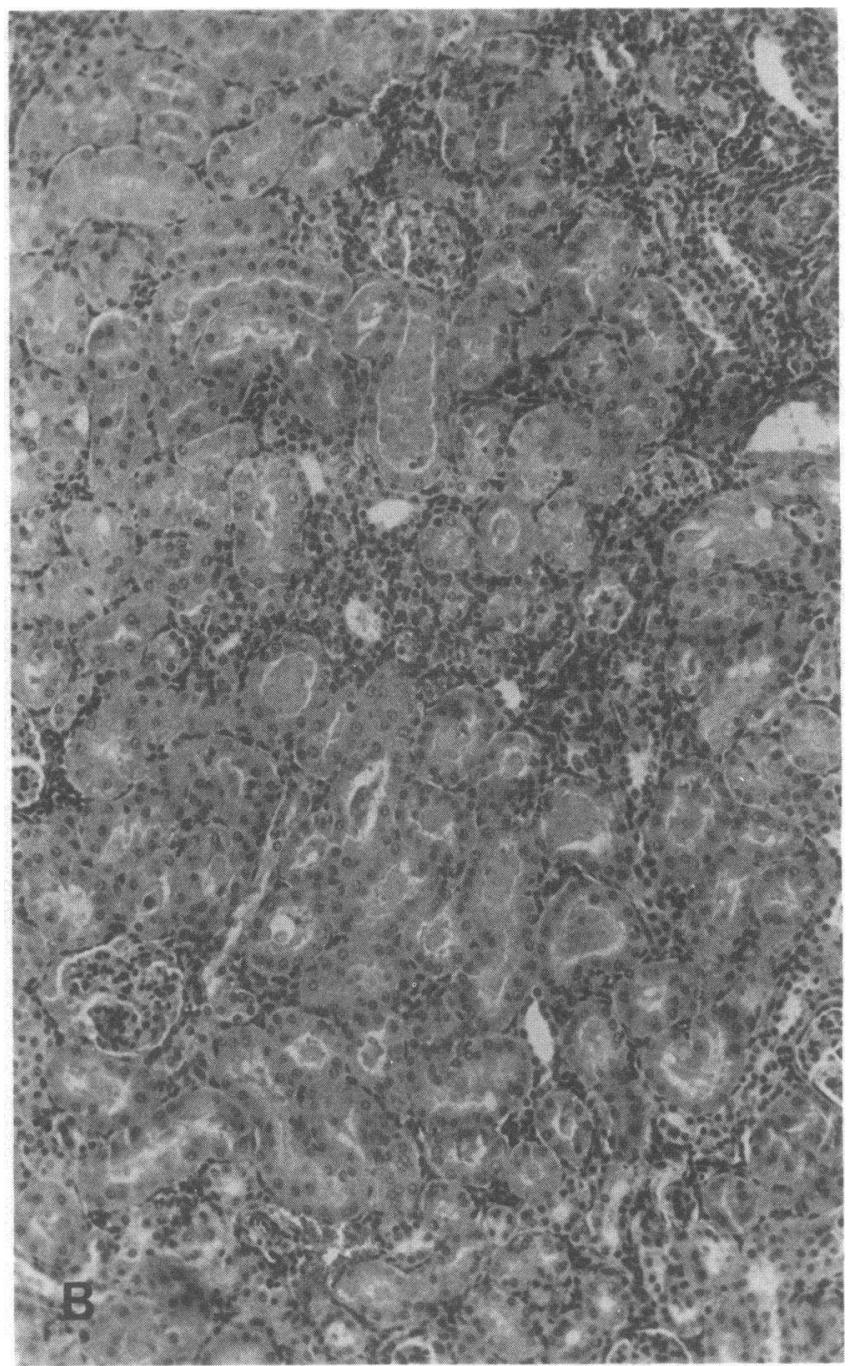

meruli are relatively uninvolved. $(B) \mathrm{LP}$ diet. The interstitium is considerably less damaged, with only a few scattered areas of mononuclear cells. Control kidneys were completely normal $(\times 250$, original magnification).

ment with $\alpha \mathrm{RT} 7.1+\mathrm{C}^{\prime}$, which indicates, again, that the DTH response was $T$ cell-dependent. In admixture adoptive transfers (Table II, group II), performed as part of the same experiment, we tested the possibility that the reduction in DTH in the LP rats (6) was due to active suppression. In these transfers, however, immune cells from LP rats failed to inhibit the DTH reaction produced by cotransferred immune cells from NP fed rats, which suggests that low protein diet did not induce a suppressor cell mechanism.

In a second series of experiments, we wished to determine the effects of LP diet on the course and extent of established disease. Groups of rats immunized with RTA/CFA or CFA alone were fed NP diet for $28 \mathrm{~d}$. At that point, each of the immunized groups were placed either on LP diet or continued on NP diet for another $\mathbf{4 2} \mathrm{d}$. In Table III, at the time of the switch to LP diet, rats immunized with RTA/CFA but fed NP diet had significant interstitial lesions $(3.0 \pm 0.2)$ and a corresponding elevated creatinine (1.78 \pm 0.6$)$ compared with rats immunized with CFA alone. At $70 \mathrm{~d}$ the group immunized with RTA/CFA and con- 


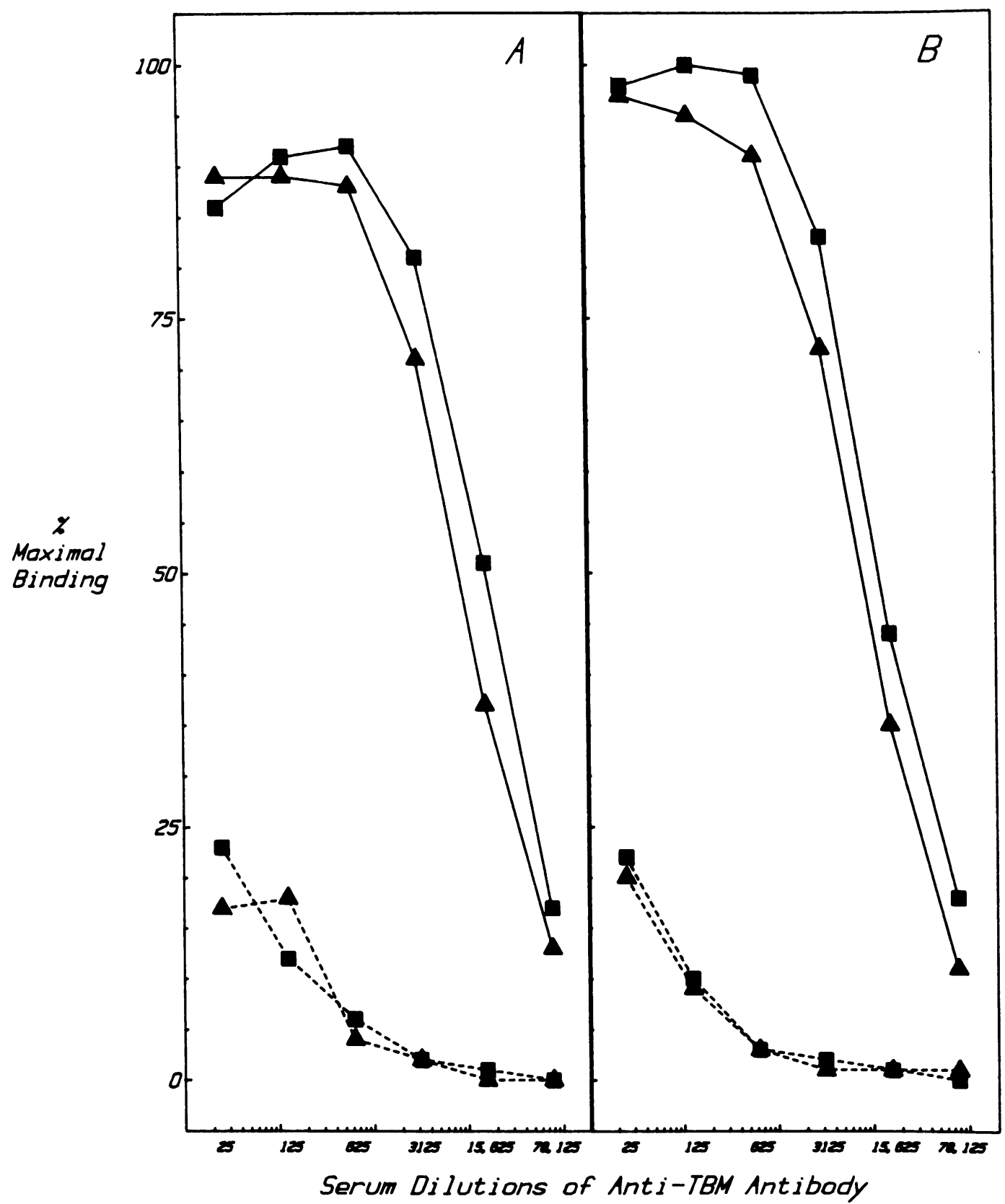

Figure 2. The effect of protein restriction on the production of $\alpha$ TBM$\mathrm{Ab}$. A radioimmunoassay for $\alpha \mathrm{TBM}-\mathrm{Ab}$ was performed, as previously described $(16,22)$, using 70-d serum samples obtained at killing from all experimental subjects: $(A)$ Serum samples obtained from rats immunized $42 \mathrm{~d}$ after the start of LP diet (Table I). (B) Serum samples obtained from rats switched to LP diet $28 \mathrm{~d}$ after immunization (Table III). For both panels: NP-RTA/CFA (曰- - $)$, LP-RTA/CFA

tinued on the NP diet had persistently evident interstitial lesions, while the lesions from the group on the LP diet were improved. Serum creatinine values were also concordantly improved in this latter group. In Fig. $2 B$, again, the switch to LP diet while altering the extent of disease did not influence the production of $\alpha \mathrm{TBM}-\mathrm{Ab}$.

\section{Discussion}

The present findings indicate that stringent protein restriction can inhibit the development of immune-mediated interstitial
$(\Delta-\Delta)$, NP-CFA $(\square---\square)$, and LP-CFA $(\Delta---\Delta)$. These results, in both panels, show a highly significant production of $\alpha$ TBM$\mathrm{Ab}$ in all groups immunized to produce disease regardless of diet (variance $<5 \%$ of the mean). The binding slopes were also nearly superimposable, which suggested that the antibodies produced in each group were qualitatively similar.

nephritis as well as ameliorate the extent of established disease. ${ }^{2}$ When protein intake in the present study was factored for the quantity ingested per kilogram body weight, the LP group ingested, on the average, $3.5 \mathrm{~g} / \mathrm{kg}$ per $\mathrm{d}$ of protein, which is ap-

2. Our study clearly demonstrates an effect of protein restriction upon the morphologic manifestations of tubulointerstitial disease. The serum creatinine measurements tended to corroborate the histologic findings, but it should be recognized that glomerular filtration rate, serum creatinine, and renal plasma flow all vary independently with weight, age, and protein intake. 
Table II. Adoptive Transfer of Immune Cells Producing DTH

\begin{tabular}{|c|c|c|c|c|c|c|}
\hline \multirow[b]{2}{*}{ Group } & \multicolumn{2}{|l|}{ Donor cells* } & \multirow{2}{*}{$\begin{array}{l}\text { Cells } \\
\text { transferred } \\
\left(\times 10^{6}\right)\end{array}$} & \multirow[b]{2}{*}{ Treatment§ } & \multicolumn{2}{|c|}{ DTH response"l } \\
\hline & Immunization & Dietł & & & SRTA & PPD \\
\hline \multirow[t]{6}{*}{ I } & RTA/CFA & NP & 20 & - & $25.8 \pm 0.8 \pi$ & $27.5 \pm 1.6 \pi$ \\
\hline & RTA/CFA & NP & 20 & $\mathrm{C}^{\prime}$ & $25.5 \pm 0.9 \pi$ & $27.2 \pm 1.2 \pi$ \\
\hline & RTA/CFA & NP & 20 & $\alpha \mathrm{T}+\mathrm{C}^{\prime}$ & $7.0 \pm 0.7$ & $5.8 \pm 0.6$ \\
\hline & RTA/CFA & LP & 20 & - & $5.2 \pm 0.6$ & $6.8 \pm 1.1$ \\
\hline & RTA/CFA & LP & 20 & $\mathrm{C}^{\prime}$ & $8.5 \pm 0.9$ & $8.8 \pm 0.6$ \\
\hline & RTA/CFA & LP & 20 & $\alpha \mathrm{T}+\mathrm{C}^{\prime}$ & $5.5 \pm 0.6$ & $6.5 \pm 0.9$ \\
\hline \multirow[t]{3}{*}{ II } & RTA/CFA & NP & 20 & & & \\
\hline & RTA/CFA & LP & $20\rangle$ & - & $26.5 \pm 0.9 \pi$ & $28.2 \pm 1.5 \pi$ \\
\hline & RTA/CFA & NP & 40 & - & $27.5 \pm 1.2 \pi$ & $27.5 \pm 0.9 \pi$ \\
\hline \multirow[t]{3}{*}{ III } & CFA & NP & 20 & - & $7.5 \pm 0.9$ & $28.0 \pm 1.5 \pi$ \\
\hline & CFA & LP & 20 & - & $7.5 \pm 0.9$ & $9.8 \pm 0.9$ \\
\hline & - & - & - & - & $4.2 \pm 0.7$ & $3.8 \pm 0.5$ \\
\hline
\end{tabular}

* Donor lymph node and spleen cells harvested from rats $28 \mathrm{~d}$ after immunization (RTA/CFA or CFA), $70 \mathrm{~d}$ after beginning on diet, were transferred into naive recipients. $¥ \mathrm{NP}$, normal calorie; or LP, normal calorie. § Some donor cells were treated before transfer with anti-T cell antibodies (anti-RT7.1) plus $\mathrm{C}^{\prime}$ or with $\mathrm{C}^{\prime}$ alone. "Five recipients of transferred cells in each group were challenged shortly after transfer, and the mean footpad increment in inches $\times 10^{-3} \pm$ SEM was determined $24 \mathrm{~h}$ later. $\pi P<0.001$, compared with controls.

proximately two-thirds the recommended minimum for the maintenance of laboratory rats (23), a figure comparable to 0.4 $\mathrm{g} / \mathrm{kg}$ per $\mathrm{d}$ for humans (24). In spite of this degree of protein restriction, the rats in the LP group maintained their body weight, although they did not grow. The protective and therapeutic effect of dietary protein reduction could not be explained by an alteration in the humoral immune response. All groups immunized with RTA/CFA, regardless of diet, made comparable amounts of $\alpha \mathrm{TBM}-\mathrm{Ab}$. The binding slopes for these $\alpha \mathrm{TBM}-\mathrm{Ab}$ were also similar, which suggests that dietary manipulation did not effect antibody affinity, either. A lack of correlation between $\alpha$ TBM$\mathrm{Ab}$ titers and the presence of interstitial lesions has been previously observed (16). BN rats immunized with RTA/CFA, for example, make large amounts of $\alpha \mathrm{TBM}-\mathrm{Ab}$, while recombinant F.BN rats made very little, but both strains develop severe disease. Susceptibility to disease and the development of interstitial lesions, in the rat, principally requires the presence of relevant antigen along the TBM $(16,25)$ and RT1-linked gene(s) for a cell-mediated immune response to tubular antigen $(16,22)$. In adoptive transfer studies, the effector $\mathrm{T}$ cell response from rats fed LP diet was nonspecifically impaired. This impairment, judged by the cell cotransfer groups (Table II, group II), was not due to an active suppressive event. It seems, therefore, that protein restriction, in the current experiments, selectively altered the effector $\mathrm{T}$ cell response, which has previously been correlated with the expression of interstitial disease $(16,22)$.

A variety of studies now suggest that moderate protein restriction, on the order of $5-11 \%$ of dietary intake, generally results in diminished antibody production with enhanced cell-mediated immunity (26-29). Severe protein restriction, on the order of $3 \%$ of dietary intake, induces near complete loss of cell-mediated immune function (6). Thus, the degree of dietary protein restriction may be critical to the overall effect on the immune system. Based on these and other observations, a few investigators have begun to examine the influence of protein and calorie re- striction on the natural history of immune-mediated renal disease. NZB and $(\mathrm{NZB} \times \mathrm{NZW}) \mathrm{F}_{1}$ mice, for example, are subject to an autoimmune disease that is, in many ways, similar to systemic lupus erythematosus in humans. These mice generally die of renal failure that is initiated by antigen-antibody immune complex-mediated injury to the glomerulus. Low protein intake (6\%) nevertheless failed to demonstrably affect immune function or the development of renal pathology in these animals $(30,31)$. A low calorie diet (32), however, preserved mouse B cell function and enhanced cell-mediated immunity while lowering anti-DNA antibody levels, reducing renal damage, and more than doubling life expectancy. Similar findings were also reported in kdkd mice, which develop an inherited interstitial nephritis similar to medullary cystic disease (33). In spite of the apparent failure of moderate protein restriction to alter the course of these renal diseases, some recent findings report that an immune-mediated form of glomerulonephritis, induced by the passive transfer of nephrotoxic antibody, was substantially ameliorated by the institution of a lower, $4 \%$ protein diet (34).

While an impairment of the cell-mediated immune response was observed at the level of protein restriction used in the present studies, other mechanisms of protection may also be equally relevant to the current observation. The effects of a marked change in dietary protein intake, for example, on the prostaglandin system, a system which may play a role in the progression of renal injury, have not been formally evaluated (6). An interactive relationship between the nephritogenic immune response and prostaglandin metabolism is equally possible. Low protein diets also have been shown to reduce the glomerular filtration rate $(34,35)$, which may be protective in certain models of progressive renal disease (36). This protection may be extended to the tubulointerstitium, because a fall in glomerular filtration can reduce mitochondrial oxygen consumption and energy expenditure by tubular cells $(35,36)$. Such metabolic conservation may be important in minimizing tubular damage (36). It is pres- 
Table III. Effects of Protein Restriction on the Progression of Interstitial Nephritis

\begin{tabular}{|c|c|c|c|c|c|c|c|c|c|}
\hline \multicolumn{3}{|l|}{ Day 0} & \multicolumn{3}{|c|}{ Day 28" } & \multicolumn{4}{|l|}{ Day 70} \\
\hline Diet* $^{*}$ & Weightf & Immunization§ & Diet & $\begin{array}{l}\text { Serum } \\
\text { creatininel }\end{array}$ & $\begin{array}{l}\text { Histological } \\
\text { severity** }\end{array}$ & Weight & $\begin{array}{l}\text { Serum } \\
\text { creatinine }\end{array}$ & $\begin{array}{l}\text { Histological } \\
\text { severity }\end{array}$ & $\begin{array}{l}\text { Bound } \\
\alpha \mathrm{TBM}-\mathrm{Ab}\end{array}$ \\
\hline NP & 113 & RTA/CFA & NP & $1.78 \pm 0.04$ & $3.0 \pm 0.2(3)$ & 156 & $1.92 \pm 0.05$ & $3.2 \pm 0.3(5) \ddagger \ddagger$ & $2.8 \pm 0.4$ \\
\hline NP & 104 & CFA & NP & $0.84 \pm 0.02$ & $0.0 \pm 0.0(3)$ & 153 & $0.74 \pm 0.02$ & $0.0 \pm 0.0(5)$ & $0.0 \pm 0.0$ \\
\hline NP & 105 & RTA/CFA & LP & $1.78 \pm 0.04$ & $3.0 \pm 0.2$ & 111 & $0.97 \pm 0.02$ & $1.4 \pm 0.2(5)$ & $3.2 \pm 0.3$ \\
\hline NP & $108^{\prime}$ & CFA & LP & $0.84 \pm 0.02$ & $0.0 \pm 0.0$ & 131 & $0.82 \pm 0.03$ & $0.0 \pm 0.0(5)$ & $0.0 \pm 0.0$ \\
\hline
\end{tabular}

\begin{abstract}
* Animals were fed NP diet until day 28 , and either the LP or NP diet from day 28 until day 70 . $¥$ Weight reported as the mean in grams. $\S$ Animals were immunized with either RTA in CFA or CFA alone. "Randomly selected animals from the RTA in CFA group or CFA group alone were killed to assess the extent of disease present before the remaining rats were placed on the various dietary regimens. I Serum creatinines (mean $\mathrm{mg} \% \pm \mathrm{SEM}$ ). ${ }^{* *}$ Graded histological sections reported as the mean extent of cortical involvement $\pm \mathrm{SEM}(n)$. $\neq ¥ P<0.04$, compared with LP-RTA/CFA group.
\end{abstract}

ently difficult to therefore eliminate the possibility of some beneficial effect of protein restriction from altered glomerular mechanics.

These results, in conclusion, demonstrate an inhibitory effect of dietary protein restriction on the development of immunemediated interstitial nephritis. Of additional interest, our observations also dissociate the influence of the humoral immune response from the suppressive effects of protein restriction on the generation of cell-mediated immunity against renal tubular antigen.

\section{Acknowledgments}

The authors would like to thank Drs. Zalman Agus and Stanley Goldfarb for their critical reading of this manuscript, and Fran Martin for her secretarial assistance.

This work was supported in part by National Institutes of Health grants AM-30280, AM-07006, AM-20553, and AM-07357. Dr. Neilson is the recipient of a Clinican-Scientist Award (80-411) from The American Heart Association. Michael D. Clayman is the recipient of a PhysicianScientist Award (AM-01303) from The National Institutes of Health.

\section{References}

1. Newburgh, L. H. 1919. The production of Bright's disease by feeding high-protein diets. Arch. Intern. Med. 24:359-377.

2. Klahr, S., J. Buerkert, and M. L. Purkerson. 1983. Dietary factors in chronic renal disease. Kidney Int. 24:579-587.

3. Bischoff, F. 1932. The influence of the diet on renal and blood changes. J. Nutr. 5:431-450.

4. Ibels, L. S., A. C. Alfrey, L. Haut, and W. E. Huffer. 1978. Preservation of function in experimental renal disease by dietary restriction of phosphate. N. Engl. J. Med. 298:122-126.

5. Brenner, B. M., T. W. Meyer, and T. H. Hostetter. 1982. Dietary protein intake and the progressive nature of kidney disease: the role of hemodynamically mediated glomerular injury in the pathogenesis of progressive glomerular sclerosis in aging, renal ablation, and intrinsic renal disease. $N$. Engl. J. Med. 307:652-659.

6. Good, R. A., G. Fernandes, E. J. Yunis, W. C. Cooper, D. C. Jose, T. R. Kramer, and M. A. Hansen. 1976. Nutritional deficiency, immunologic function, and disease. Am. J. Pathol. 84:599-614.

7. Neilson, E. G., and B. Zakheim. 1983. T cell regulation, antiidiotypic immunity, and the nephritogenic immune response. Kidney Int. 24:289-302.
8. Andres, G., and R. T. McCluskey. 1978. Proliferative and exudative glomerulonephritides. In Immunologically Mediated Renal Diseases. G. Andres and R. T. McCluskey, editors, Marcel Dekker, New York. 1516.

9. Bohle, A., H. Christ, K. E. Grund, and S. Makensen. 1979. The role of the interstitium of the renal cortex in renal disease. Contrib. Nephrol. 16:109-114.

10. Sloper, J. C., H. deWardener, and D. F. Woodrow. 1980. Relationship between renal structure and function deduced from renal biopsies. In Renal Pathophysiology. A. Leaf, G. Giebisch, L. Bolis, and S. Gorini, editors. Raven Press, New York. 109-120.

11. Van Ypersele de Strihou, C. 1979. Acute oliguric interstitial nephritis. Kidney Int. 16:751-765.

12. Murray, T., and M. Goldberg. 1975. Chronic interstitial nephritis: etiologic factors. Ann. Intern. Med. 82:953-459.

13. Andres, G. A., and R. T. McCluskey. 1975. Tubular and interstitial renal disease due to immunologic mechanisms. Kidney Int. 7:271-289.

14. Neilson, E. G., and S. M. Phillips. 1979. Cell-mediated immunity in interstitial hephritis. I. T lymphocyte systems in nephritic guinea pigs: the natural history and diversity of the immune response. J. Immunol. 123:2373-2380.

15. Neilson, E. G., and S. M. Phillips. 1982. Murine interstitial nephritis. I. Analysis of disease susceptibility and its relationship to pleiomorphic gene products defining both immune response genes and a restrictive requirement for cytotoxic T cells at H-2K. J. Exp. Med. 155: 1075-1085.

16. Neilson, E. G., D. L. Gasser, E. McCafferty, B. Zakheim, and S. M. Phillips. 1983. Polymorphism of genes involved in anti-tubular basement membrane disease in rats. Immunogenetics. 17:55-65.

17. Neilson, E. G., and S. M. Phillips. 1982. Suppression of interstitial nephritis by auto-anti-idiotypic immunity. J. Exp. Med. 155:179-189.

18. Clark, C. C. 1979. The distribution and internal characterization of oligosaccharide units on the $\mathrm{COOH}$-terminal propeptide extensions of the pro- 21 and pro- 22 chains of type 1 procollagen. J. Biol. Chem. 259:10798-10802.

19. Rudofsky, U. H. 1976. Studies on the pathogenesis of experimental autoimmune renal tubulointerstitial disease in guinea pigs. Clin. Exp. Immunol. 25:455-461.

20. Bieri, J. G., G. S. Stoewsand, G. M. Briggs, R. W. Phillips, J. C. Woodard, and I. J. Knapka. 1977. Report of the American Institute of Nutrition Ad Hoc Committee on Standards for Nutritional Studies. $J$. Nutr. 107:1340-1348.

21. Husdan, H., and A. Rapoport. 1968. Estimation of creatinine by the Jaffe reaction. A comparison of three methods. Clin. Chem. 14: 222-238.

22. Neilson, E. G., E. McCafferty, S. M. Phillips, M. D. Clayman, 
and C. J. Kelly. 1984. Antiidiotypic immunity in interstitial nephritis. II. Rats developing anti-tubular membrane disease fail to make an antiidiotypic regulatory response: the modulatory role of an $\mathrm{RT} 7.1^{+}, \mathrm{OX8}^{-}$ suppressor T cell mechanism. J. Exp. Med. 159:1009-1026.

23. National Research Council-Committee on Animal Nutrition. 1978. Recommended Nutrient Allowances for Domestic Animals. National Academy of Sciences, Washington. 10:7-38.

24. Scrimshaw, N. S. 1976. An analysis of past and present recommended dietary allowances for protein in health and disease. $N$. Engl. J. Med. 294:136-198.

25. Matsumoto, K., E. McCafferty, E. G. Neilson, and D. L. Gasser. 1984. Mapping of the genes for tubular basement membrane antigen and a submaxillary gland protease in the rat. Immunogenetics. 20:117124.

26. Kenney, M. A., C. F. Roderuck, L. Arnrich, and F. Piedad. 1983. Effect of protein deficiency on the spleen and antibody formation in rats. J. Nutr. 95:173-178.

27. Mathor, M., V. Ramalingaswam, and M. G. Deo. 1972. Influence of protein deficiency on $19 \mathrm{~S}$ antibody-forming cells in rats and mice. $J$. Nutr. 102:841-846.

28. Cooper, W. C., R. A. Good, and T. Mariani. 1974. Effects of protein insufficiency on immune responsiveness. Am. J. Clin. Nutr. 27: 647-664.
29. Good, R. A., A. West, and G. Fernandes. 1980. Nutritional modulation of immune responses. Fed. Proc. 39:3098-3104.

30. Fernandes, G., E. J. Yunis, and R. A. Good. 1976. Influence of protein restriction on immune functions in NZB mice. J. Immunol. 116: 782-790.

31. Fernandes, G., E. J. Yunis, and R. A. Good. 1976. Influence of diet on survival of mice. Proc. Natl. Acad. Sci. USA. 73:1279-1283.

32. Fernandes, G. P. Friend, E. J. Yunis, and R. A. Good. 1978. Influence of dietary restriction on immunologic function and renal disease in (NZB $\times$ NZW) $F_{1}$ mice. Proc. Natl. Acad. Sci. USA. 75:1500-1504.

33. Fernandes, G., E. J. Yunis, M. Miranda, J. Smith, and R. A. Good. 1978. Nutritional inhibition of genetically determined renal disease and autoimmunity with prolongation of life in kdkd mice. Proc. Natl. Acad. Sci. USA. 75:2888-2892.

34. Neugarten, J., H. D. Feiner, R. G. Schacht, and D. S. Baldwin. 1983. Amelioration of experimental glomerulonephritis by dietary protein restriction. Kidney Int. 24:595-601.

35. Katz, A. I., and F. H. Epstein. 1968. Physiologic role of sodiumpotassium-activated adenosine triphosphatase in the transport of cations across biologic membranes. $N$. Engl. J. Med. 278:253-261.

36. Alfrey, A. C., and R. C. Tomford. 1984. The case of tubulointerstitial factors. In Controversies In Nephrology and Hypertension, R. G. Narins, editor. Churchill-Livingston, New York, 557-566. 